\title{
Proliferation of Salvinia molesta at Lake Kyoga Landing Sites as a Result of Anthropogenic Influences
}

\author{
Morgan Andama*, Robert Ongom, Ben Lukubye \\ Department of Biology, Faculty of Science, Mbarara University of Science and Technology, Mbarara, Uganda \\ Email: *amorgan@must.ac.ug, *andamamorgan@gmail.com
}

How to cite this paper: Andama, M., Ongom, R. and Lukubye, B. (2017) Proliferation of Salvinia molesta at Lake Kyoga Landing Sites as a Result of Anthropogenic Influences. Journal of Geoscience and Environment Protection, 5, 160-173. https://doi.org/10.4236/gep.2017.511012

Received: September 26, 2017 Accepted: November 19, 2017 Published: November 22, 2017

Copyright ( 92017 by authors and Scientific Research Publishing Inc. This work is licensed under the Creative Commons Attribution International License (CC BY 4.0).

http://creativecommons.org/licenses/by/4.0/

\begin{abstract}
Salvinia molesta (native of south-eastern Brazil) is a free floating aquatic fern that has spread to several countries around the globe including Uganda. Under optimum growing conditions, the plant is capable of spreading rapidly where it can have immense environmental, economic and human health impacts. Thick mats of the weed have been recorded in some parts of Lake Kyoga, Uganda where it hinders the abstraction of water, docking and boat take-off, bathing and swimming activities. Therefore this study aimed to determine the extent of $S$. molesta at selected landing sites in Lake Kyoga and the influence of anthropogenic activities on the weed coverage as well as the effect of physico-chemical parameters of the water on the development of the weed. Quadrats were used to ascertain the coverage of $S$. molesta while the physico-chemical parameters were determined by standard methods. The results showed significant positive correlation of $S$. molesta weed coverage with phosphates $\left(\mathrm{PO}_{4}-\mathrm{P}\right)$ and negative correlations with $\mathrm{pH}$, dissolved oxygen (DO) and water flow rate. Though statistically insignificant waste sites recorded the highest overall $S$. molesta coverage $\left(82.61 \pm 21.12 \mathrm{~m}^{2}\right)$ per $400 \mathrm{~m}^{2}$ quadrat followed by boat docks $\left(82.24 \pm 19.45 \mathrm{~m}^{2}\right)$, gardens $\left(50.93 \pm 11.82 \mathrm{~m}^{2}\right)$ and finally fishing areas $\left(27.94 \pm 5.93 \mathrm{~m}^{2}\right)$ respectively. The overall weed coverage was highest around the shoreline locations of Acholi inn landing site $\left(101.72 \pm 22.89 \mathrm{~m}^{2}\right.$ per $\left.400 \mathrm{~m}^{2}\right)$ followed by Masindi port $\left(60.39 \pm 15.64 \mathrm{~m}^{2}\right)$, Waitumba $\left(41.89 \pm 10.55 \mathrm{~m}^{2}\right)$ and the least in the offshore location at Kayei landing site $\left(39.71 \pm 10.17 \mathrm{~m}^{2}\right)$. Salvinia molesta distribution in Lake Kyoga is linked to nutrient $\left(\mathrm{PO}_{4}-\mathrm{P}\right)$ supply, proximity to the shoreline and the associated anthropogenic activities. Hence waste sites, gardens and boat docks enhance $S$. molesta invasion in Lake Kyoga. Therefore, sources of nutrients (phosphates) into Lake Kyoga that favour the proliferation of $S$. molesta should be minimized through adequate waste treatment and prohibition of
\end{abstract}


cultivation close to the lake. Salvinia molesta coverage along the routes of moving boats should also be contained so as to reduce the spread of the weed in the lake through boat movements. Furthermore, eradication efforts of $S$. molesta weed in Lake Kyoga should be heightened at the shoreline areas of the lake in the various landing sites within the lake basin.

\section{Keywords}

Freshwater, Human Activities, Invasive Weed, Management, Uganda

\section{Introduction}

Lake Kyoga is a large shallow lake in Uganda of about $1720 \mathrm{~km}^{2}$ (660 sq. miles) in area with mean depth of $3.6 \mathrm{~m}$ and maximum depth of $6 \mathrm{~m}$ [1] [2]. About 9.3 million people inhabit Lake Kyoga Basin and their major economic activity is agricultural productivity (crop growing and livestock farming) practiced by $85 \%$ of the population [2] [3]. Fishing is also carried out on the lake by an estimated 200,000 people and the lake is used for inland water transport as well as source of water for drinking and other domestic uses for most of the inhabitants in the lake basin [4] [5] [6]. Unfortunately, Lake Kyoga has been invaded by the free-floating aquatic weed, giant Salvinia molesta D.S. Mitchell with a high potential to infest the numerous satellite lakes in Kyoga Basin [7]. Therefore, there is an urgent need to collect baseline data and information on the extent of $S$. molesta infestation in the Kyoga Basin lakes [7].

Salvinia molesta belongs to Order Hydropteridales, Family Salvinanceae and genus Salvinia with about 12 species which are all native to South America [8] [9]. Salvinia molesta formally existed only in South America, but since the 1940s the weed has been dispersed by humans to different tropical and subtropical countries in Africa, Asia, and Australia [10] [11] as well as USA in the recent years [12]. The plant is known by a number of common names such as giant Salvinia, Kariba weed, aquarium water moss, water fern, and giant azalea etc. These names often reflect the environment the weed inhabits or its invasiveness [13] [14]. The weed is called "Nankabirwa" by locals in Uganda, due to lack of a native name [15].

The free-floating $S$. molesta weed comprises of an underneath horizontal rhizome which lies close to the water surface [16]. It has two types of leaves (buoyant and submerged leaves) attached to each node of the rhizome. The submerged leaves of $S$. molesta are modified to perform the function of roots as the weed does not have true roots [17]. S. molesta exhibits several morphological variations ranging from slender floating plant with less than $15-\mathrm{mm}$ wide leaves to a robust plant having leaves up to $60-\mathrm{mm}$ wide brought about by crowding and nutrient availability in the habitat [17] [18] [19]. The weed is capable of spreading easily over water bodies using its floating structures and even survives in unfavourable environments using the most suitable growth form [20]. It seemingly 
produces only sterile spores, hence reproduces entirely by vegetative means which can be extremely rapid under suitable conditions [18]. For instance, $S$. molesta can double in biomass in 2 to 3 days under favourable conditions [21]. This enables $S$. molesta to out-compete other plant species and completely cover the water surface with mats as thick as $1 \mathrm{~m}$ [22].

Salvinia molesta has been recently added onto the list of the world's 100 most invasive species and ranks second to water hyacinth (Eichhornia crassipes, (Mart.) Solms-Laub.) as the most invasive aquatic plant in the world due to its environmental, economic and human health impacts [23] [24]. S. molesta poses similar problems as those posed by Water Hyacinth and Water Lettuce including clogging canals, rivers and lakes; displacing native plants and animals; and interfering with irrigation, navigation, fishing and electric power generation activities [25]. The thick mat formed by the weed covers the water surface and blocks light penetration into the water. The thick mat also severely reduces dissolved oxygen content (DO) in aquatic ecosystems sometimes resulting into fish kills [7] [14]. For the case of Lake Kyoga, the thick mats of $S$. molesta on the lake (Figure 1) have hampered activities such as abstraction of water by surrounding communities, watering of domestic animals, docking and boat take-off, bathing and swimming [7].

Fortunately $S$. molesta weed has been successfully managed in other countries e.g. lake Moondara, Australia where the weed had threatened the biodiversity and the life of the lake [26]. Studies in Australia showed that successful management of Salvinia molesta is achieved through integrated control strategies combining herbicide spraying, biological control agents and mechanical removal including the containment of the weed to keep some areas free of $S$. molesta [27]. The control strategy depends on the level of infestation and the conditions in the areas of infestation [27]. However, the best management practices for Salvinia in Africa can be found from those countries (e.g. Zimbabwe and Kenya) where the weed is non native but has apparently not led to major disruptions to use of water resources [7] as well as Senegal, Mauritania [17] and South Africa [28] among other countries where successful control by biological agent (Cyrtobagous
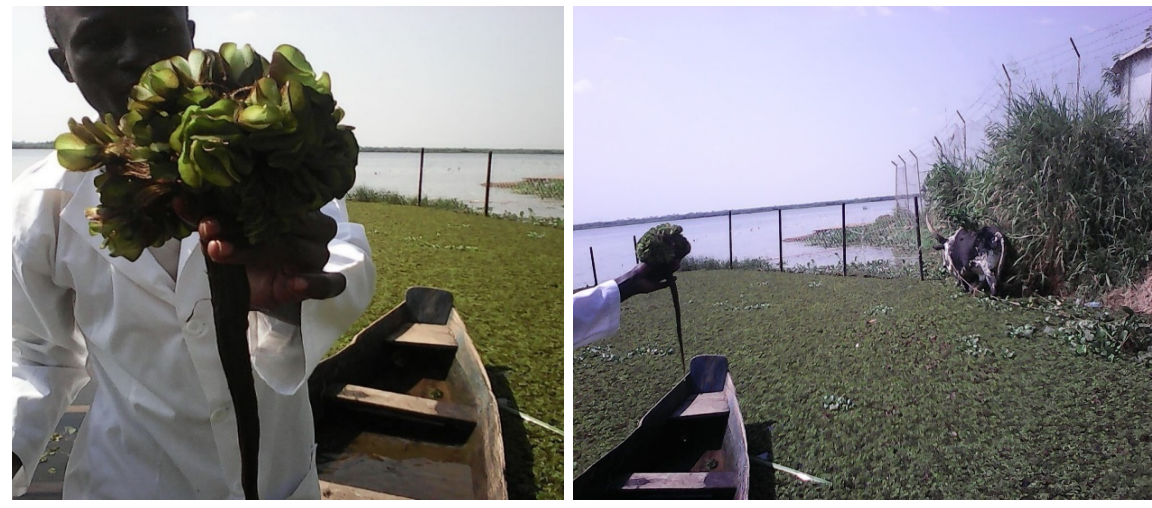

Figure 1. Picture of Salvinia molesta and coverage of the weed at a boat dock in Waitumba landing site in Lake Kyoga. Source: Field Data. 
salviniae) was achieved. The use of Cyrtobagous salviniae biological agent to control $S$. molesta in these countries was based on the outstanding success of Cyrtobagous salviniae in Australia and Papua New Guinea [29] [30] [31] [32].

Nevertheless, planning a management strategy for $S$. molesta involves identification of the source of the infestation, mapping the infestation, identification and minimising sources of nutrients entering the water body [27]. The nutrient sources include livestock handling areas, garden runoff, cropping and agriculture, erosion of cultivated land, urban sewage outflows and industrial wastewater among others [27]. For the case of Lake Kyoga, gully erosion, wastes from human activities and livestock are the potential sources of nutrients (mainly phosphorus and nitrogen) into the lake [33] [34]. The generated wastes in Lake Kyoga catchment are untreated with high levels of pollutants like phosphates and nitrates [6]. These nutrients create favourable conditions for Salvinia molesta infestation of Lake Kyoga.

However, there has been inadequate study and management of $S$. molesta weed on Lake Kyoga as evidenced by the outcry of the people in Lake Kyoga basin from Salvinia infestation with its devastating environmental and socio-economic impacts [7]. Hence an urgent intervention to control the noxious S. molesta weed in Lake Kyoga is required so as to fully use and exploit the resources of the lake. This study therefore determined the proliferation of Salvinia molesta weed at selected landing sites in Lake Kyoga as a result of anthropogenic influences and some physico-chemical parameters that favour the multiplication of $S$. molesta in Lake Kyoga in a bid to control the weed.

\section{Materials and Methods}

\subsection{Location of Study Area}

Lake Kyoga (Figure 2) lies on the central African plateau (altitude of $1100 \mathrm{~m}$ ), north of Lake Victoria at coordinates $1^{\circ} 15^{\prime}-1^{\circ} 45^{\prime} \mathrm{N} ; 31^{\circ} 31^{\prime}-33^{\circ} 31^{\prime} \mathrm{E}$. It is the largest lake among the Kyoga aquatic system [35]. Dense swamps $\left(2000 \mathrm{~km}^{2}\right.$ in area) comprising mainly of extensive mats of Cyperus papyrus L. surround the shores of Lake Kyoga and the numerous tributaries of the lake [36] [37]. These wetlands create small bays close to the shorelines of the lake which support the establishment of $S$. molesta [23]. The lake is surrounded by fishing villages with the people using boats for fishing and inland water transport hence there are several boat landing sites along the shores of the lake. Furthermore, garbage from peoples' homes and surrounding hotels are damped near the lake and cultivation is also done close to the lake. These anthropogenic activities are practiced at all the landing sites in the Lake Kyoga basin. Therefore, in order to determine the extent of $S$. molesta coverage as influenced by the anthropogenic activities (boat dock, waste site, garden, fishing), four landing sites on Lake Kyoga namely; Waitumba at geographical coordinates $\left(1.6993^{\circ} \mathrm{N}, 32.0988^{\circ} \mathrm{E}\right)$, Masindi port $\left(1.6986^{\circ} \mathrm{N}, 32.0982^{\circ} \mathrm{E}\right)$, Acholi inn $\left(1.6726^{\circ} \mathrm{N}, 32.2601^{\circ} \mathrm{E}\right)$ and Kayei $\left(1.6767^{\circ} \mathrm{N}, 32.3934^{\circ} \mathrm{E}\right)$ were purposively selected for the study. The sampling 


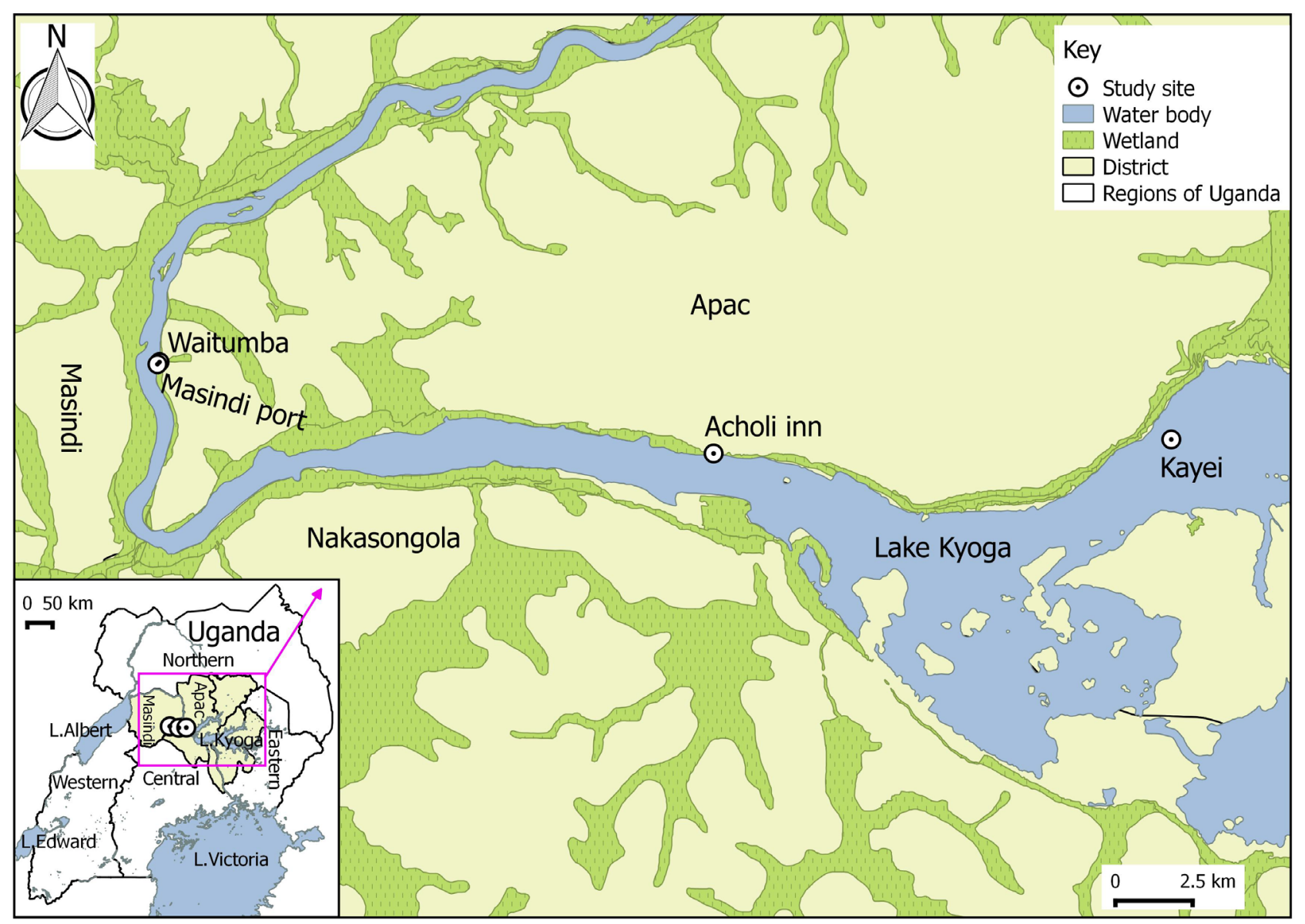

Figure 2. Map of Uganda showing Lake Kyoga and the location of the study sites. Source: Modified from Ongom et al. [38].

points at Waitumba, Masindi port and Acholi inn landing sites were close to the shoreline of the lake while the sampling points at Kayei landing site were slightly offshore (Figure 2). The weed coverage was determined at or near waste sites (damping areas for mainly organic wastes from hotels and homes), garden, boat dock and fishing areas in the landing sites.

\subsection{Sampling and Determination of $S$. molesta Coverage in Lake Kyoga}

The coverage of $\mathcal{S}$. molesta was determined using the quadrat method [39] [40] [41]. Six plots (quadrats) each measuring $20 \mathrm{~m}$ by $20 \mathrm{~m}\left(400 \mathrm{~m}^{2}\right)$ were randomly set at or near the identified anthropogenic activities (boat dock, waste site, garden and fishing areas) in the landing sites (Kayei, Acholi inn, Waitumba and Masindi port). Four boats were arranged in the water at a distance of $20 \mathrm{~m}$ from one another to form the square plot $\left(400 \mathrm{~m}^{2}\right)$ at each of the sampling sites. Various shapes/figures (e.g. rectangular, triangular, square etc) formed by the $S$. molesta mat on the surface of the water in the $400 \mathrm{~m}^{2}$ area were established and their dimensions measured using a tape measure. The area of each shape/figure (square, rectangle, triangle) of $S$. molesta mat in the $400 \mathrm{~m}^{2}$ area was then calculated and the total area of the weed coverage in the $400 \mathrm{~m}^{2}$ area obtained by 
summing up the respective areas of the mats. Water samples were also collected and on-site measurements taken around the $S$. molesta mats in the study sites to determine the physico-chemical parameters that favour the multiplication of $S$. molesta or are compromised by its spread [38]. Field work was done in one sampling period starting from December, 2015 to January, 2016.

\subsection{Data Analysis}

The data were summarized in form of descriptive statistics (minimum, maximum, standard deviation, mean, standard error of the mean) and presented in tables and bar graphs. Comparisons of $S$. molesta coverage across the various landing sites and anthropogenic activities were done using Kruskal Wallis $(\mathrm{H})$ test while relationships between coverage and physico-chemical parameters explored using spearman's correlation coefficient $\left(r_{s}\right)$ at $5 \%$ level of significance. Normality of data and homogeneity of variance confirmed using Kolmogorov Smirnov (KS) and Levene (L) tests respectively informed the choice of the test statistics. The analyses were done using Microsoft Excel 2007 and SPSS 20 Computer packages.

\section{Results and Discussion}

\section{Salvinia molesta Coverage at Landing Sites and Anthropogenic Activities in Lake Kyoga}

Salvinia molesta coverage exhibited high variability within samples in the different landing sites and anthropogenic activities i.e. coefficient of variation, CV (landing sites $=110.24 \%-126.89 \%$; human activities $=103.97 \%-125.26 \%$ ). Acholi inn landing site had the overall highest mean coverage followed by Masindi port, Waitumba and finally Kayei (Table 1) though the variations were insignificant $(p>0.05)$. S. molesta coverage was the highest at the boat docks

Table 1. Descriptive statistics of Salvinia molesta coverage on Lake Kyoga across different landing sites and anthropogenic activities and comparison using Kruskal Wallis $(\mathrm{H})$ test.

\begin{tabular}{|c|c|c|c|c|c|c|c|c|c|}
\hline Parameters & Location & Site/Activity & Min. & Max. & SD & CV (\%) & Mean \pm SE & $\mathrm{H}$ & $p$ \\
\hline \multirow{8}{*}{$\begin{array}{c}\text { S. molesta } \\
\text { coverage } \\
\left(\mathrm{m}^{2} / 400 \mathrm{~m}^{2}\right) \\
(\mathrm{n}=24)\end{array}$} & \multirow{4}{*}{$\begin{array}{l}\text { Landing } \\
\text { Site }\end{array}$} & Kayei & 0.00 & 194.56 & 49.81 & 125.46 & $39.71 \pm 10.17$ & \multirow{4}{*}{5.57} & \multirow{4}{*}{0.14} \\
\hline & & Acholi inn & 0.00 & 382.83 & 112.13 & 110.24 & $101.72 \pm 22.89$ & & \\
\hline & & Waitumba & 0.20 & 160.98 & 51.69 & 123.39 & $41.89 \pm 10.55$ & & \\
\hline & & Masindi port & 0.00 & 347.48 & 76.63 & 126.89 & $60.39 \pm 15.64$ & & \\
\hline & \multirow{4}{*}{$\begin{array}{l}\text { Human } \\
\text { Activity }\end{array}$} & Boat dock & 0.00 & 306.71 & 95.29 & 115.87 & $82.24 \pm 19.45$ & \multirow{4}{*}{4.10} & \multirow{4}{*}{0.25} \\
\hline & & Waste site & 5.59 & 382.83 & 103.47 & 125.26 & $82.61 \pm 21.12$ & & \\
\hline & & Garden & 0.00 & 207.17 & 57.90 & 113.67 & $50.93 \pm 11.82$ & & \\
\hline & & Fishing & 0.00 & 142.60 & 29.05 & 103.97 & $27.94 \pm 5.93$ & & \\
\hline
\end{tabular}

Not significant $(p>0.05)$; Min.: minimum; Max.: maximum; SD: standard deviation; SE: Standard error of the mean; CV.: coefficient of variation; $\mathrm{H}$ used when data are not normally distributed (KolmogorovSmirnov $p<0.05)$ and variances are different (Levene $p<0.05)$. 
followed by waste sites, gardens and fishing areas in Acholi inn and Waitumba landing sites (Figure 3 ) however the results were not significantly different. Boat docks in Acholi inn had significantly more weed coverage than those in Masindi port, Waitumba and Kayei landing sites respectively. Whereas the weed coverage was the highest at waste sites (damping areas for mainly organic wastes from hotels and homes) followed by boat docks, gardens and the least in the fishing areas in Masindi port $(p>0.05)$. Waste sites also had the highest weed coverage followed by the gardens, fishing areas and finally the boat docks in Kayei landing site $(p>0.05)$. Waste sites generally recorded the highest coverage of $S$. molesta followed by boat docks, gardens and lastly fishing areas and the difference however were insignificant. As there is poor waste management around African Great Lakes including Lake Kyoga [42] [43], the high coverage of $\mathcal{S}$. molesta around the waste sites is expected. According to Arti [14], improper waste management transform ecosystems and lead to proliferation of invasive species. It is also worth noting that boat docks in Acholi inn had the highest weed coverage among all the studied sites.

Spearman's correlation of $S$. molesta coverage with selected physico-chemical parameters [38] showed significant positive correlation with $\mathrm{PO}_{4}-\mathrm{P}\left(\mathrm{r}_{s}=0.27, p=\right.$ $0.01, \mathrm{n}=96)$. This is supported by previous studies which established that growth rates of $S$. molesta increase with increase in nutrients (e.g. phosphorus) supply [8] [44]. On the other hand, there were significant negative correlations with $\mathrm{pH}\left(\mathrm{r}_{\mathrm{s}}=-0.23, p=0.02, \mathrm{n}=96\right)$, dissolved oxygen $\left(\mathrm{r}_{\mathrm{s}}=-0.22, p=0.03, \mathrm{n}=\right.$ 96) and water flow rate $\left(\mathrm{r}_{\mathrm{s}}=-0.46, p=0.02, \mathrm{n}=24\right)$. According to Madsen and

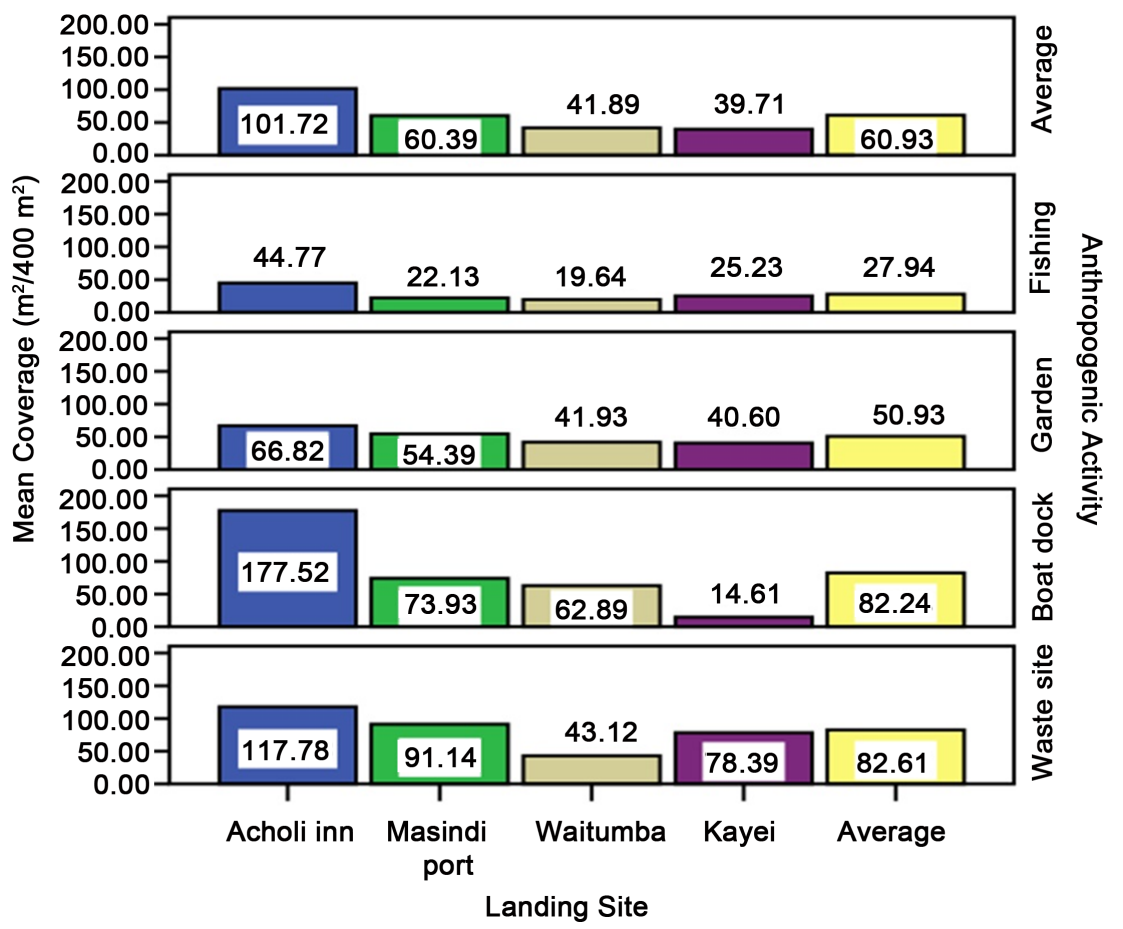

Figure 3. Coverage of Salvinia molesta at sampled landing sites and separated into anthropogenic activities in Lake Kyoga. 
Wersal [24], S. molesta grows well at relatively lower $\mathrm{pH}$ than higher $\mathrm{pH}$. When the authors investigated the growth rates of the weed in $\mathrm{pH}$ values between 5 and 8 , increased biomass was obtained at $\mathrm{pH}$ of 6 and 6.5 compared to biomass at higher $\mathrm{pH}$ ranges. Furthermore, solid mats of $S$. molesta hinder gas exchange and often times build up carbon dioxide levels in the water column causing acidification of the waterway hence reduction of $\mathrm{pH}$ [45]. The above findings justify the negative correlation of $S$. molesta coverage with $\mathrm{pH}$ in the present study. The thick $S$. molesta mats also lower the concentration of dissolved oxygen in water column [46] hence explaining the negative correlation of dissolved oxygen with $S$. molesta coverage. The negative correlation of $S$. molesta coverage with water flow rate obtained in this study is expected since $S$. molesta grows best in stagnant or slowly moving waters [25]. Furthermore, flushing usually moves infestations of $S$. molesta according to van Oosterhout [27].

The lower coverage of $S$. molesta in Kayei and higher coverage in the other landing sites (Acholi inn, Waitumba, Masindi port) can be respectively attributed to the offshore and shoreline locations of the sampling areas at the landing sites (Figure 2). According to Aloo et al. [47], aquatic weeds thrive most along the shores of water bodies. In addition, CABI [23] reported that $S$. molesta prefers small bays and inlets of dissected shorelines with less wave action. Furthermore, Wanda et al. [7] found out that $S$. molesta was well established along most of the shoreline in the central and western zones of Lake Kyoga. In addition to protection of $S$. molesta from wave action, the shoreline areas are also richer in nutrients than the offshore locations due to their lower depths. Hecky and Bugenyi [48] obtained higher concentrations of phosphorus $\left(\mathrm{P}-\mathrm{PO}_{4}\right)$ near the mud surface (closer to the shoreline) than the upper photosynthetic zone. Hence the high coverage of $S$. molesta near the shoreline areas may be linked to the rich organic material usually found at the lake bottoms along the shorelines. This is reflected by the high phosphate $\left(\mathrm{PO}_{4}-\mathrm{P}\right)$ levels in Acholi inn landing site (Figure 4) though Masindi port, Waitumba and Kayei landing sites had phosphate values contrary to the average $S$. molesta coverage at those sites (Figure 3 ).

There was accumulation of phosphates $\left(\mathrm{PO}_{4}-\mathrm{P}\right)$ at Kayei landing site (Figure 4) resulting from less uptake by $S$. molesta at low coverage. On the other hand, the high coverage of the weed at Waitumba and Masindi port landing sites might have led to the depletion of phosphates $\left(\mathrm{PO}_{4}-\mathrm{P}\right)$ in the water at those sites due to increased uptake by the weed. According to Divakaran et al. [49], the rapid proliferation of $S$. molesta causes depletion of nutrients. However, $S$. molesta carriage through attachment on boats increased the weed coverage at Acholi inn landing site (Figure 3) which also recorded high phosphates (Figure 4) at the same time. The enriched phosphates in Acholi inn could have resulted from the decay of organic matter in the habitat of the weed [14]. According to Lavelle and Spain [50], organic matter decomposition is a good source of phosphorus.

The high coverage of $S$. molesta at waste sites and gardens (Figure 3 ) is associated with increased nutrient $\left(\mathrm{PO}_{4}-\mathrm{P}\right)$ availability (Figure 4$)$ as the $\mathrm{pH}(6.73-7.15)$ 

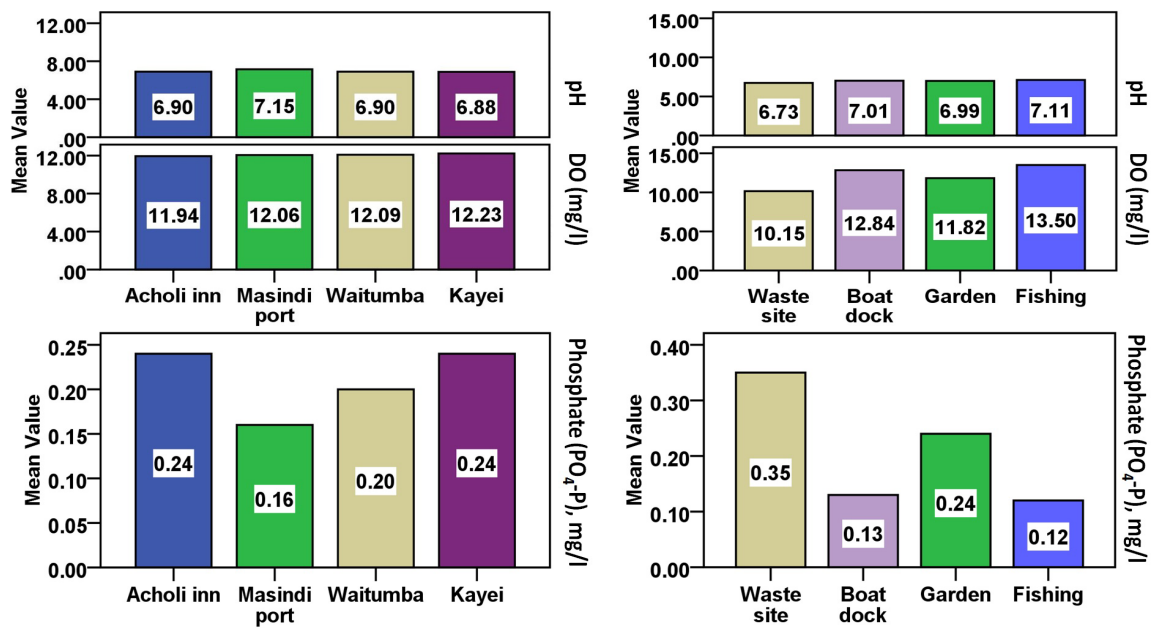

Figure 4. Selected physico-chemical parameters at the landing sites and anthropogenic activities. Source: Modified from [38].

and temperature $\left(25.06^{\circ} \mathrm{C}-25.76^{\circ} \mathrm{C}\right)$ ranges at all the study sites were relatively constant and suitable for growth of the weed. According to Cary and Weerts [44], S. molesta grows optimally in nutrient-rich (e.g. P) conditions at $\mathrm{pH} 6$ - 7.5 and water temperatures ranging from $20^{\circ} \mathrm{C}$ to $30^{\circ} \mathrm{C}$. However, nutrient availability is more influential to the growth of the weed than $\mathrm{pH}$ [14]. The high coverage of $S$. molesta weed close to the waste sites and gardens is expected as growth of aquatic weeds (e.g. $S$. molesta) increases with increase in agricultural productivity [51]. This is due to the fact that agricultural and wastewater runoffs into freshwater ecosystems enrich the nutrient levels in the water bodies [14]. For the case of Lake Kyoga, about $85 \%$ of the population in the lake basin is currently engaged in agriculture [3] hence increased cultivation and livestock rearing around the lake. On the other hand, more wastes have also been discharged into the lake from increased human activities and livestock in the lake basin thus elevating phosphate levels in the lake [34] [52].

The high coverage of $S$. molesta at boat docks despite the relatively lower nutrient $\left(\mathrm{PO}_{4}-\mathrm{P}\right)$ levels is attributable to the weed getting stuck on boats and then washed off in the boat docks. Global Invasive Species Database [53] showed that S. molesta can be spread within and between water-bodies by contaminated boats. The weed often gets caught in boats and the plant fragments are carried to new areas [13] [21]. According to Parsons and Cuthbertson [54] and Gewertz [55], S. molesta spread between aquatic systems as a hitchhiker on boats, or in shipments of fish is common. For example, the spread of $S$. molesta into inland waterways of Zimbabwe was associated with the boat movements to and from Lake Kariba [56]. As Lake Kyoga is very much used for fishing [4] and inland water transport [57], the number of boats on the lake is high hence increased coverage of $S$. molesta at the boat docks.

The coverage of the $S$. molesta at the different landing sites and anthropogenic activities decreased the concentrations of dissolved oxygen at those sites in line with previous studies which indicated that solid mats of $S$. molesta reduce the 
dissolved oxygen concentrations in the water column [14] [58]. For instance, dissolved oxygen concentration underneath $S$. molesta mats in Lake Naivasha only attained $10 \%$ saturation as opposed to $64 \%-85 \%$ in the open water [59]. The relatively high dissolved oxygen (DO) concentrations recorded at the boat docks (Figure 4) despite the high weed coverage (Figure 3 ) is probably due to the constant breaking of the thick $S$. molesta mats and mixing of the water at the boat docks as a result of boat movements. According to Wanda et al. [7], the brittle stolons of $S$. molesta are easily broken by the movement of boats. Ongom et al. [38] also reported that mixing of Lake Kyoga water increases the oxygen circulation in the lake. $S$. molesta weed coverage was the least in the fishing areas (Figure 3) associated with low nutrient $\left(\mathrm{PO}_{4}-\mathrm{P}\right)$ concentrations (Figure 4) and the low weed coverage also resulted into increased dissolved oxygen concentrations at the fishing areas.

\section{Conclusion}

Salvinia molesta distribution in Lake Kyoga is linked to nutrient $\left(\mathrm{PO}_{4}-\mathrm{P}\right)$ supply, proximity to the shoreline and the associated anthropogenic activities. Hence waste sites, gardens and boat docks enhance $S$. molesta invasion in Lake Kyoga. Therefore, sources of nutrients (phosphates) into Lake Kyoga that favour the proliferation of $S$. molesta should be minimized through adequate waste treatment and prohibition of cultivation close to the lake. Salvinia molesta coverage along the routes of moving boats should also be contained so as to reduce the spread of the weed in the lake through boat movements. Furthermore, eradication efforts of $\mathcal{S}$. molesta weed in Lake Kyoga should be heightened at the shoreline areas of the lake in the various landing sites within the lake basin.

\section{Acknowledgements}

The authors greatly acknowledge the technical support of National Water and Sewerage Corporation, Masindi most especially during field sampling. The authors are also grateful to the Department of Biology, Mbarara University of Science and Technology for their guidance and support throughout the research period and preparation of this paper.

\section{References}

[1] Ogutu-Ohwayo, R., Hecky, R.E., Cohen, A.S. and Kaufman, L. (1997) Human Impacts on the African Great Lakes. Environmental Biology of Fishes, 50, 117-131. https://doi.org/10.1023/A:1007320932349

[2] Japan International Cooperation Agency, JICA (2011) The Development Study on Water Resources Development and Management for Lake Kyoga Basin in the Republic of Uganda. Final Report Summary. http://open_jicareport.jica.go.jp/pdf/12025201_01.pdf

[3] Kaggwa, R., Hogan, R. and Gowa, E. (2004) Policy Brief: Land Use Change, Land Degradation and Human Welfare: Lessons Learned from the Lake Kyoga Catchment Area. UNDP-UNEP Poverty-Environment Initiative, Nairobi. 
[4] Gyllenhammar, A. (n.d.) Using Modeling, Gis and Remote Sensing to Understand an African Lake. http://wldb.ilec.or.jp/ILBMTrainingMaterials/resources/Kyoga.pdf

[5] State of the River Nile Basin (2012) The Role of Inland Water Transport in Support of Further Regional Integration. http://nileis.nilebasin.org/system/files/Nile\%20SoB\%20Report $\% 20$ Chapter\%207\%2 0-\%20Transport.pdf

[6] Fisheries Training Institute (2004) Selected Fish Landing Sites and Fishing Communities. Survey Undertaken by Fisheries Training Institute for the DFID Project: Impacts of Globalisation on Fish Utilisation and Marketing Systems in Uganda. https://assets.publishing.service.gov.uk/media/57a08cd8e5274a31e00014b2/R8112k. pdf

[7] Wanda, F.M., Balirwa, J.S., Ogwanga, J.A., Moro, R. and Amondito, B. (2015) A New Water Weed, Giant Salvinia (Salvinia molesta), Invades Lake Kyoga, Jinja, Uganda. National Fisheries Resources Research Institute.

http://aquaticcommons.org/20322/1/A\%20new\%20water\%20weed\%2Cgiant\%20sal vinia.pdf

[8] Room, P.M. and Thomas, P.A. (1986) Population Growth of the Floating Weed Salvinia molesta: Field Observation and a Global Model Based on Temperature and Nitrogen. Journal of Applied Ecology, 23, 1013-1028. https://doi.org/10.2307/2403952

[9] Nelson, L. (2014) Giant and Common Salvinia. In: Gettys, L.A., Haller, W.T. and Petty, D.G., Eds., Biology and Control of Aquatic Plants. A Best Management Practices Handbook, 3rd Edition, Aquatic Ecosystem Restoration Foundation, Marietta, GA, 157-164. http://www.aquatics.org/bmp\%203rd\%20edition.pdf

[10] Pieterse, A.H. (2000) Aquatic Weed Management. In: van Rijn, P.J., Ed., Weed Management in the Humid and Sub-humid Tropics, Royal Tropical Institute, Amsterdam, 169-176.

[11] Sculthorpe, C.D. (1967) The Biology of Aquatic Vascular Plants. Edwards Arnold, London.

[12] Jacono, C.C. (1999) Salvinia molesta (Salviniaceae), New to Texas and Louisiana. Sida, 18, 927-928.

[13] McFarland, D.G., Nelson, L.S., Grodowitz, M.J., Smart, R.M., Mitchell, D.S. and Owens, C.S. (2004) Salvinia molesta (Giant Salvinia) in the United States: A Review of Species Ecology and Management. Aquatic Plant Control Research Programm. http://acwc.sdp.sirsi.net/client/search/asset/1002855;jsessionid=9163D57D15D87D CC8A51D2DE051B93EC.enterprise-15000

[14] Arti, L. (2016) Salvinia molesta: An Assessment of the Effects and Methods of Eradication. Master's Projects and Capstones, 572.

http://repository.usfca.edu/capstone/572

[15] Wandera, S. (2015) Egypt in Research on Uganda's Dangerous New Water Weed. http://mobile.monitor.co.ug/News/Egypt-research-Uganda-s-dangerous-new-water -weed/2466686-3006260-format-xhtml-bppacuz/index.html

[16] Bonnet, A.L.M. (1955) Contribution to the Study of Hydropteridees: Research on Salvinia auriculata Aubl. Annals of Botanical and Natural Sciences. Plant Biology, 16, 529-601.

[17] Pieterse, A.H., Kettunen, M., Diouf, S., Ndao, I., Sarr, K., Tarvainen, A., Kloff, S. and Hellsten, S. (2003) Effective Biological Control of Salvinia molesta in the Senegal River by Means of the Weevil Cyrtobagous salviniae. AMBIO: A Journal of the Human Environment, 32, 458-462. https://doi.org/10.1579/0044-7447-32.7.458 
[18] Mitchell, D.S. and Tur, N.M. (1975) The Rate of Growth of Salvinia molesta ( $S$. auriculata Auct.) in Laboratory and Natural Conditions. Journal of Applied Ecology, 12, 213-225. https://doi.org/10.2307/2401730

[19] Ashton, P.J. and Mitchell, D.S. (1989) Aquatic Plants: Pattern and Modes of Invasion, Attributes of Invading Species and Assessment of Control Programmes. In: Drake, J.A., Mooney, H.A., di Castri, F., Groves, R.H., Kroger, J., Rejmánek, R. and Williamson, M., Eds., Biological Invasions: A Global Perspective, John Wiley, Chichester, 111-154.

[20] Oliver, J.D. (1993) A Review of the Biology of Giant Salvinia (Salvinia molesta Mitchell). Journal of Aquatic Plant Management, 31, 227-231.

[21] Room, P.M. (1990) Ecology of a Simple Plant-Herbivore System. Biological Control of Salvinia. Trends in Ecology and Evolution, 5, 74-79. https://doi.org/10.1016/0169-5347(90)90234-5

[22] Room, P.M. and Thomas, P.A. (1986) Nitrogen, Phosphorus and Potassium in Salvinia molesta Mitchell in the Field: Effects of Weather, Insect Damage, Fertilizers and Age. Aquatic Botany, 24, 213-232. https://doi.org/10.1016/0304-3770(86)90058-6

[23] CABI (2017) Datasheet, Salvinia molesta (Kariba Weed). http://www.cabi.org/isc/datasheet/48447

[24] Madsen, J.D. and Wersal, R.M. (2008) Growth Regulation of Salvinia molesta by pH and Available Water Column Nutrients. Journal of Freshwater Ecology, 23, 305-313. https://doi.org/10.1080/02705060.2008.9664203

[25] Labrada, R. and Fornasari, L. (2002) Management of Problematic Aquatic Weeds in Africa: FAO Efforts and Achievements during the Period 1991-2001. FAO, Rome.

[26] Forno, I.W. (1987) Biological Control of the Floating Fern Salvinia molesta in North Eastern Australia: Plant-Herbivore Interactions. Bulletin of Entomological Research, 77, 9-17. https://doi.org/10.1017/S0007485300011482

[27] van Oosterhout, E., Coventry, R., Julien, M. and Rainbird, R. (2006) Salvinia Control Manual. Management and Control Options for Salvinia (Salvinia molesta) in Australia. NSW Department of Primary Industries, Sydney.

[28] Cilliers, C.J. (1991) Biological Control of Water Fern, Salvinia molesta (Salviniaceae), in South Africa. Agriculture, Ecosystems and Environment, 37, 219-224. https://doi.org/10.1016/0167-8809(91)90150-V

[29] Room, P.M., Harley, K.L.S., Forno, I.W. and Sands, D.P.A. (1981) Successful Biological Control of the Floating Weed Salvinia. Nature, 294, 78-80. https://doi.org/10.1038/294078a0

[30] Room, P.M., Sands, D.P.A., Forno, I.W., Taylor, M.F.J. and Julien, M.H. (1985) A Summary of Research into Biological Control of Salvinia in Australia. In: Delfosse, E.S., Ed., Proceedings of the Sixth International Symposium on the Biological Control of Weeds, Vancouver, 19-25 August 1984, 543-549.

[31] Thomas, P.A. and Room, P.M. (1985) Towards Biological Control of Salvinia in Papua New Guinea. In: Deifosse, E.S., Ed., Proceedings of the Sixth International Symposium on the Biological Control of Weeds, Vancouver, 19-25 August 1984, 567-574.

[32] Thomas, P.A. and Room, P.M. (1986) Taxonomy and Control of Saivinia molesta. Nature, 320, 581-584. https://doi.org/10.1038/320581a0

[33] National Environment Management Authority (NEMA) (2001) National State of the Environment Report for Uganda, 2000/2001. National Environment Management Authority (NEMA), Kampala. 
[34] National Environment Management Authority, NEMA (2008) Pilot Integrated Environment Assessment of the Lake Kyoga Catchment Area. National Environment Management Authority (NEMA), Kampala.

[35] Burgis, M. and Symoens, J.J. (1987) Lake Kyoga and Associated Lakes. In: African Wetlands and Shallow Water Bodies.

[36] Mungoma, S. (1988) Horizontal Differentiation in the Limnology of a Tropical River-Lake (Lake Kyoga, Uganda). Hydrobiologia, 162, 89-96. https://doi.org/10.1007/BF00014336

[37] Twongo, T. (1991) The Fisheries of the Kyoga Lakes and the Likely Impact on Them by Human Activities in the Catchment. Uganda Freshwater Fisheries Research Organization, Jinja.

[38] Ongom, R., Andama, M. and Lukubye, B. (2017) Physico-Chemical Quality of Lake Kyoga at Selected Landing Sites and Anthropogenic Activities. Journal of Water Resource and Protection, 9, 1225-1243. https://doi.org/10.4236/jwarp.2017.911080

[39] Baxter, J. (n.d.) Vegetation Sampling Using the Quadrat Method. https://www.researchgate.net/file.PostFileLoader.html?id=57c5b20adc332d2a05424 4ad\&assetKey=AS\%3A400818403594240\%401472573962223

[40] Curtis, J.T. and Mcintosh, R.P. (1950) The Interrelations of Certain Analytic and Synthetic Phytosociological Characters. Ecology, 31, 434-455. https://doi.org/10.2307/1931497

[41] Cottam, G. and Curtis, J.T. (1956) The Use of Distance Measures in Phytosociological Sampling. Ecology, 37, 451-460. https://doi.org/10.2307/1930167

[42] Cohen, A.S., Kaufman, L. and Ogutu-Ohwayo, R. (1996) Anthropogenic Threats, Impacts and Conservation Strategies in the African Great Lakes-A Review. In: Johnson, T.C. and Odada, E., Eds., The Limnology, Climatology and Paleoclimatology of the East African Lakes, Gordon \& Breach Scientific Publishers, Toronto.

[43] Nriagu, J. (1992) Toxic Metal Pollution in Africa. The Science of the Total Environment, 121, 1-37. https://doi.org/10.1016/0048-9697(92)90304-B

[44] Cary, P.R. and Weerts, P.G.J. (1983) Growth of Salvinia molesta as Affected by Water Temperature and Nutrition: Effects of Nitrogen Level and Nitrogen Compounds. Aquatic Botany, 16, 163-172. https://doi.org/10.1016/0304-3770(83)90091-8

[45] Julien, M., McFadyen, R. and Cullen, J. (2012) Biological Control of Weeds in Australia. CSIRO Publishing, Clayton.

[46] Mitchell, D.S. (1979) The Incidence and Management of Salvinia molesta in Papua, New Guinea. Department of Primary Industry, Papua New Guinea, 62.

[47] Aloo, P., Ojwang, W., Omondi, R., Njiru, J.M. and Oyugi, D. (2013) A Review of the Impacts of Invasive Aquatic Weeds on the Biodiversity of Some Tropical Water Bodies with Special Reference to Lake Victoria (Kenya). Biodiversity Journal, 4, 471-482.

[48] Hecky, R.E. and Bugenyi, F.W.B. (1992) Hydrology and Chemistry of the Great Lakes and Water Quality Issues: Problems and Solutions. Mitteilungen Internationale Vereinigung für Limnologie, 23, 45-54.

[49] Divakaran, O., Arunachalam, M. and Balakrishnan Nair, N. (1980) Growth Rates of Salvhtia molesta with Special Reference to Salinity. Plant Science, 89, 161-168.

[50] Lavelle, P. and Spain, A.V. (2001) Soil Ecology. Kluwer Academic Publishers, New York. https://doi.org/10.1007/978-94-017-5279-4 
[51] Davis, R. and Hirji, R. (2003) Water Resources and Environment, Technical Note C.2. Environmental Flows: Case Studies. Management of Aquatic Plants. Technical Note G4, The World Bank Publication, Washington DC.

[52] National Fisheries Resources Research Institute, NaFIRRI (2007) A Study on Stock Enhancement/Restocking of the Kyoga Basin Lakes. A Review of Kyoga Basin Lakes. National Fisheries Resources Research Institute (NaFIRRI), Jinja.

[53] Global Invasive Species Database (2010) Salvinia molesta (Aquatic Plant, Herb). http://issg.org/database/species/ecology.asp?si=569\&fr=1\&sts=\&lang=EN

[54] Parsons, W.T. and Cuthbertson, E.G. (1992) Noxious Weeds of Australia. Inkata Press, Melbourne, $692 \mathrm{p}$.

[55] Gewertz, D.B. (1983) Sepik River Societies. Yale University Press, New Haven, 196-217.

[56] Chikwenhere, G.P. and Keswani, C.L. (1997) Economics of Biological Control of Kariba Weed (Salvinia molesta Mitchell) at Tengwe in North-Western Zimbabwe-A Case Study. International Journal of Pest Management, 43, 109-112. https://doi.org/10.1080/096708797228780

[57] State of the River Nile Basin (2012) The Role of Inland Water Transport in Support of Further Regional Integration.

http://nileis.nilebasin.org/system/files/Nile\%20SoB\%20Report\%20Chapter\%207\%2 0-\%20Transport.pdf

[58] Petr, T. (2000) Interactions between Fish and Aquatic Macrophytes in Inland Waters. A Review. FAO Fisheries Technical Paper No. 396, FAO, Rome.

[59] Kongere, P.C. (1979) The Salvinia Infestation on Lake Naivasha in Kenya. Swedish Fund-in-Trust, Project TF-RAF 112(SWE), Suppl. 1, FAO, Rome, 143-153. 